\title{
Relatos orais de famílias de imigrantes japoneses: Elementos para a história da educação brasileira
}

\section{Zeila de Brito Fabri Demartini*}

\begin{abstract}
RESUMO: Este artigo dá continuidade a uma reflexão que vimos realizando há muitos anos sobre a estruturação do campo educacional paulista e as diferentes formas pelas quais a procura pela escolarização tem se configurado para diferentes setores da população rural e urbana no estado de São Paulo. Focalizamos aqui o segmento representado pelas famílias de imigrantes japoneses que vieram para São Paulo a partir de 1908. Apresentamos os resultados obtidos em estudo sobre as famílias de imigrantes japoneses na cidade de São Paulo, sendo que os relatos orais foram a fonte privilegiada que permitiu, de um lado, apreender as visões e vivências educacionais desse grupo, e, de outro, obter informações valiosas sobre a ainda desconhecida rede de escolas "japonesas" criadas por esse grupo na sociedade paulistana.
\end{abstract}

Palavras-chave: Educação e diferenciação sociocultural, educação em São Paulo, escolas japonesas, japoneses em São Paulo, História da Educação

Introdução

Este artigo é parte de estudo mais amplo sobre famílias de imigrantes japoneses na cidade de São Paulo, em que focalizamos nossa atenção nos temas relativos a educação, hábitos culturais e atividades de lazer. ${ }^{1}$

Abordaremos aqui especificamente o campo da educação escolar: de um lado, como foi se estruturando uma rede de escolas japonesas pa-

* Docente da Faculdade de Educação/Unicamp e pesquisadora do Ceru/USP. Participaram também desta pesquisa: Gilmar Santana, Maria Helena Lara Netto, Odila Carvalho Reis, Valéria Barbosa de Magalhães. E-mail: ceru@edu.usp.br 
ralelamente ao sistema público estadual; de outro, as estratégias individuais e coletivas desenvolvidas pelas famílias japonesas no campo da educação escolar, tentando apreender as ambigüidades e os conflitos vivenciados, decorrentes da orientação voltada tanto para a manutenção da cultura japonesa como para a procura de uma cultura nacional, discutindo a prática de uma educação igualitária num contexto de diferenças socioculturais.

Nesse estudo trabalhamos com fontes diversificadas, mas foram privilegiados os relatos orais, baseando-nos nas orientações e discussões por nós já elaboradas anteriormente. As entrevistas foram realizadas com homens e mulheres de gerações sucessivas de várias famílias japonesas que trabalharam em áreas rurais e famílias que se inseriram no mercado urbano de São Paulo, famílias que residiam em "colônias" e famílias que moravam "isoladas". Entrevistamos tanto indivíduos que nasceram no Japão, como os nascidos no Brasil, no início da imigração e em períodos posteriores. Também realizamos algumas entrevistas com professores não-japoneses que conviveram com esse grupo de imigrantes.

\section{A importância da educação para os imigrantes}

A bibliografia que trata o tema educação entre os japoneses revelanos uma preocupação acentuada dos nipônicos com a educação de seus filhos aqui no Brasil; essa atitude seria uma continuidade do que ocorria no Japão no início do século XX (Demartini 1995). Como afirma Miyao (1980, p. 91):

A revolução política e social iniciada na Era Meiji, em 1868, trouxe profunda transformação no regime da nação nipônica, dando prioridade à difusão da educação, difundindo-a de modo drástico, (...). Desde então o Japão emergiu de uma nação fechada, de 300 anos de isolacionismo, conseguindo rápida modernização com a introdução maciça da cultura ocidental. O japonês que viveu uma época assim peculiar sentia no seu âmago que a instrução era a coisa mais importante da vida, sobrepondo-se a qualquer outra opção. O imigrante japonês que começou a chegar ao Brasil em 1908 também foi criado nesse ambiente.

Outro fator que deve ter influenciado a educação dos japoneses era seu alto grau de escolaridade, que superava o de outros países, com exceção dos imigrantes alemães; foi o que constatou a Secretaria de Agricultura do Estado de São Paulo quando fez um levantamento a esse respeito com 
imigrantes que desembarcaram no Porto de Santos entre 1908 e 1932. O percentual de japoneses com idade superior a 12 anos não-analfabetos era de $89,9 \%$, enquanto entre os imigrantes italianos era de $71,36 \%$; entre os imigrantes portugueses, $51,7 \%$; entre os imigrantes espanhóis era de $46,3 \%$ e ntre os imigrantes alemães, $91,1 \%$ (Vários Autores 1992, p. 143).

Nas colônias japonesas essa preocupação pode ser constatada por meio da organização de associações que tinham por objetivo, em primeiro lugar, suprir a educação dos filhos e promover a cooperação entre os membros e a comunicação entre os núcleos coloniais existentes. Antes mesmo de sedes de associações para seus encontros comunitários e sociais, os japoneses procuravam construir a escola. Era aí que se reuniam para discutir os problemas da comunidade ou simplesmente comer e beber (Handa 1987).

Quando se fundava uma associação, muitos só vinham por saber que haveria escola na colônia (núcleo). A maior parte dos pais queria que seus filhos aprendessem a língua e os costumes japoneses, tendo em vista o retorno a seu país de origem; caso as crianças não fossem educadas à maneira japonesa, poderiam ser marginalizadas ao voltar. O grande dilema dos pais era optar entre os interesses econômicos e a educação: seria melhor guardar o dinheiro para o retorno ao Japão ou empregá-lo na educação dos filhos? De qualquer modo, nenhum pai desejava ter filhos "caboclos"; assim, procuravam fazer com que eles pudessem também freqüentar o ginásio da cidade. Portanto, tornava-se necessário construir escolas particulares, pois o governo brasileiro não construía escolas nem mesmo para as crianças brasileiras em idade escolar, deixando aos imigrantes a resolução de suas questões educacionais (Demartini 1988).

\section{A freqüência da população japonesa em diferentes tipos de escolas}

Com as levas de imigrantes japoneses para São Paulo surgiu uma diversidade de escolas, cujos nomes conhecemos dos relatos dos informantes, dada a dificuldade de se obter uma relação dessas escolas em São Paulo e adjacências. Mesmo em anuários sobre a educação desse período (por exemplo, o Annuario do Ensino do Estado de São Paulo, publicação organizada pela Directoria Geral da Instrução Publica com autorização do governo do Estado) são raríssimas as citações, ao contrário do que ocorre com as escolas italianas.

Para compreendermos melhor o funcionamento e a importância das escolas para a comunidade nipônica, procuramos analisá-las em dois as- 
pectos: a) os diferentes tipos de escolas criadas e b) suas transformações segundo os diferentes momentos vivenciados pelos japoneses em São Paulo.

Consideramos que a escolarização da população japonesa passou por dois momentos no período anterior à Segunda Guerra Mundial. O primeiro caracteriza-se pelo grande e intenso processo de criação de escolas particulares japonesas e por sua procura; o segundo é marcado pelas medidas nacionalistas do governo Getúlio Vargas, que condena veementemente a educação japonesa, induzindo à transformação dessas escolas ou provocando seu desaparecimento.

Segundo vários autores, no início da imigração a escola construída pelos japoneses, principalmente nas colônias, não exigia muitos gastos. Dependendo do caso servia uma casa de pau-a-pique, sendo as paredes de barro, a cobertura de sapé e o chão batido. Se o número de alunos fosse pequeno, as aulas podiam ser ministradas em alguma casa particular; uma das entrevistadas informou que em sua casa havia funcionado uma escola, durante algum tempo, na área rural da metrópole. Inicialmente, o local em que funcionava a escola não tinha muita importância; era preferível improvisar a não ter, pensavam os japoneses. A precariedade do ensino também ocorria pela falta de livros japoneses, pois os existentes haviam sido trazidos por algum imigrante.

Um de nossos entrevistados, que imigrou sozinho em 1938, falounos da rudeza do material com que foi feita a Escola de Bastos, na qual inclusive foi professor de japonês: a escola foi construída "(...) com madeira redonda quando corta do mato (tronco de árvore) e correnteado com arame, e o telhado... é também tábua" (Entrevistado Y).

Essas escolas eram construídas com o esforço dos pais e da associação, a qual conseguia o dinheiro necessário para a construção, que, em alguns casos, era feita em poucos dias (de três a cinco), ou nos finais de semana. Além da escola, construía-se, também, a casa do professor.

De acordo com Tomoo Handa (1987), essas primeiras escolas das colônias atendiam somente as crianças, excluindo os adolescentes. Os meninos de 14,15 anos e os rapazes com mais de 20 anos tinham feito pelo menos o primário no Japão, porém, aqui no Brasil, tinham poucas oportunidades de ler revistas ou livros, o que deixava a educação recebida defasada.

Para esses jovens criavam-se nas colônias as escolas noturnas, em geral, com aulas nos domingos à noite. No princípio essas escolas só ensinavam o idioma japonês, mas com o passar dos anos incorporaram o ensino do português. Elas eram usuais em colônias do interior, tendo sido freqüentadas 
por alguns entrevistados na fazenda de Guatapará e em outras fazendas do noroeste.

O governo considerava as primeiras escolas japonesas em núcleos não-urbanos como casos isolados. A partir da década de 1930 o Departamento de Educação do Estado de São Paulo tornou obrigatório o registro da escola dos núcleos de colonização como Escola Mista Rural; tal registro garantia o ensino do japonês como disciplina extracurricular, sendo o português parte do currículo regular.

O número de escolas japonesas existentes no estado de São Paulo, principalmente no início dos anos 30 , era muito grande. O jornal Jihô, em levantamento realizado em abril de 1932 pela Associação de Pais e Alunos de Escolas Primárias Japonesas de São Paulo, informava seus leitores que nesse ano havia 178 estabelecimentos para o ensino do idioma japonês no estado e mais 20 escolas ainda não oficializadas, todas freqüentadas somente por filhos de japoneses.

Quadro I - Escolas Japonesas: localização e alunos (abril de 1932)

\begin{tabular}{|c|c|c|}
\hline ZONAS DE LOCALIZAÇÃO & $\mathrm{N}^{\circ}$ DE ESCOLAS & $\mathrm{N}^{\circ}$ DE ALUNOS \\
\hline São Paulo e seus subúrbios & 10 & 618 \\
\hline Santos e Santos-Juquiá & 10 & 364 \\
\hline Registro e suas vizinhanças & 10 & 427 \\
\hline E.F. Paulista & 13 & 544 \\
\hline São Paulo-Railway* & 5 & 120 \\
\hline E.F. Central do Brasil & 3 & 140 \\
\hline E.F. Mojiana & 0 & 0 \\
\hline E.F. Araraquara & 6 & 181 \\
\hline E.F. Douradense & 2 & 46 \\
\hline E.F. Sorocabana & 36 & 1.760 \\
\hline E.F. Noroeste & 83 & 4.669 \\
\hline TOTAL & 178 & 8.869 \\
\hline
\end{tabular}

* Atual Santos-Jundiaí

Fonte: Uma epopéia moderna, p. 126

Após localizar as escolas japonesas, o jornal Jihô tecia alguns comentários sobre os problemas enfrentados pelas escolas particulares pertencentes aos estrangeiros, pois era um período em que aumentava o nacionalismo por parte da população e do governo. 
(...) Entre as escolas particulares administradas por estrangeiros havia tendência de ensinar a língua, a geografia e a história do país de origem, e cultivando o amor à pátria dos ancestrais, obedecendo apenas formalmente às leis de ensino do Estado de São Paulo. Tal fato provocou na opinião pública brasileira uma reação, exigindo-se a fiscalização mais rigorosa dessas escolas. As autoridades estaduais de ensino realizaram uma inspeção geral, constatando-se então a existência de muitas irregularidades e contravenções. Esses fatos foram divulgados nos jornais, o que despertou a atenção dos brasileiros, irritando-os. Mesmo entre as escolas primárias administradas por japoneses, duas ou três foram fechadas. Mas, posteriormente, tendo obedecido às normas legais, tiveram autorização de funcionar.

(...) O método de ensino na seção de idioma nipônico nas escolas segue geralmente o modelo japonês, regime de seis anos, havendo alguns estabelecimentos que mantêm cursos acima do primário. As matérias são vernáculo, educação moral, aritmética, geografia, história, ciências, ginástica e canções. Os livros escolares estavam baseados nos textos oficiais de ensino primário do Ministério da Educação do Japão. De maneira que havia muitas coisas incompreensíveis para os alunos, por muito que o professor se esforçasse em explicá-las.

O ensino brasileiro segue naturalmente a orientação das leis de ensino do Estado. As classes têm aulas no período da manhã e aulas à tarde.

Merece atenção o seguinte fato. Havendo diferenças entre o professor japonês e o brasileiro, no tocante aos ideais, disciplina e método de ensino, aquilo que o aluno aprende no período da manhã pode ser rejeitado na aula da tarde. O aluno fica confuso e daí pode surgir um desentendimento entre os dois mestres-escolas (...).

As despesas de manutenção são quase inteiramente arcadas pela entidade mantenedora. Em princípio, somente as escolas oficialmente reconhecidas recebem o subsídio do governo japonês. A receita provém da mensalidade escolar, contribuição social (mensalidade paga à Associação de Japoneses pelos sócios), doações espontâneas, subsídio oficial, etc. O principal item das despesas é a remuneração do professor, mínima de 100 mil-réis e máxima de 400 mil-réis. (...) Quanto à mensalidade escolar, varia conforme a situação dos pais (proprietário ou arrendatário e ainda do número de crianças que uma família manda à escola; recolhe-se o mínimo de 1 mil-réis e o máximo de 18 mil-réis, por cabeça. (Vários Autores 1992, pp. 126-127) 
Pelos dados do Quadro II podemos perceber que havia não só um número já elevado de escolas japonesas no estado de São Paulo, mas que o número de professores de japonês superava o de português.

Quadro II - Escolas primárias de japoneses.

Tipo de escolas e de professores (em abril de 1932)

\begin{tabular}{|l|c|c|c|c}
\hline \multicolumn{1}{|c|}{ ESCOLA } & NÚMERO & PROF. JAP. & PROF. PORT. & TOTAL \\
\hline Estadual & 24 & 22 & 23 & 45 \\
\hline Estadual e particular & 23 & 27 & 23 & 50 \\
\hline Particular & 54 & 75 & 46 & 121 \\
\hline Ainda não reconhecida & 27 & 34 & 13 & 47 \\
\hline Municipal & 18 & 18 & 20 & 38 \\
\hline Municipal e particular & 10 & 11 & 15 & 26 \\
\hline Sem comunicação & 31 & 24 & 1 & 25 \\
\hline \multicolumn{1}{r|r|r|r|}{ TOTAL } & 185 & 211 & 141 & 352 \\
\hline
\end{tabular}

Fonte: Uma epopéia moderna, p. 213

Mais importante que esses aspectos, entretanto, é a constatação de que as escolas japonesas, já no início da década de 1930, eram integrantes do sistema público de educação, seja como escolas estaduais ou municipais, seja assumindo a forma mista de escolas estaduais/particulares ou municipais/particulares ( $40 \%$ do total). Essa forma de funcionamento foi citada por alguns entrevistados, como veremos mais adiante, configurando-se como uma das estratégias de inserção da educação japonesa no sistema educacional paulista e paulistano. Muitas dessas escolas construídas pelos pais japoneses passavam depois para a rede oficial.

Quadro III - Freqüência em diferentes tipos de escolas

\begin{tabular}{|l|c|c|c|c|c}
\hline \multicolumn{1}{|c|}{ TIPO DE ESCOLA } & IMIGRANTE & $\begin{array}{c}1^{\mathrm{a}} \\
\text { GERAÇÃO }\end{array}$ & $\begin{array}{c}2^{\mathrm{a}} \\
\text { GERAÇÃO }\end{array}$ & $\begin{array}{c}3^{\mathrm{a}} \mathrm{E} 4^{\mathrm{a}} \\
\text { GERAÇÕES }\end{array}$ & TOTAL \\
\hline Escola brasileira & 20.053 & 179.196 & 155.014 & 24.182 & 378.445 \\
\hline $\begin{array}{l}\text { Escola brasileira }+ \\
\text { Nitigo Gakko }\end{array}$ & 3.898 & 22.731 & 20.024 & 2.707 & 9.360 \\
\hline Nitigo Gakko & 1.175 & 1.408 & 1.271 & 137 & 3.991 \\
\hline
\end{tabular}

Fonte: Censo do Consulado Japonês, 1962 
O sistema educacional constituído pelas diferentes modalidades de escolas japonesas não atendia a toda a população de descendência japonesa, e mesmo na primeira geração de migrantes foram muitos os que freqüentaram escolas não-japonesas.

Mas havia também as ambigüidades e os conflitos dos próprios pais. $\mathrm{Na}$ cidade de São Paulo algumas famílias colocavam seus filhos em escola pública, como relata uma senhora nissei nascida em 1928 em São Paulo, porque achavam que a educação brasileira era prioritária: "Meu pai falou assim: que já que eu nasci aqui, tinha que ir no grupo escolar. (...) Tem que aprender português daqui, não é?" (Entrevistada K). Outra senhora nos contou sobre o interesse de seu pai em que os filhos tivessem uma educação brasileira, tanto que ela própria não aprendeu o japonês:

É. Se eu tivesse aprendido desde pequenininha como a minha irmã, ela já foi desde o jardim, já aprendeu a falar muito bem o japonês desde pequena e isso foi ótimo. Mas eu aí fiz o meu primário, naquele tempo o ensino era muito desorganizado, sabe? Não era como agora que tem escolas por toda a parte. (Entrevistada C)

Esses pais eram tachados de excêntricos, pois dizia-se que só a escola brasileira não era conveniente aos filhos, porque não se preocupava em ensinar a "devoção filial" (oya-koko), ou seja, a obrigação do filho em relação aos pais, que chega a durar a vida toda. Para continuar transmitindo os valores culturais japoneses era preciso dar educação à maneira japonesa, com ênfase principalmente na língua.

Os pais temiam que seus filhos estudando em escolas brasileiras fossem se abrasileirando e desse modo perdessem o elo com a cultura japonesa. $\mathrm{Na}$ realidade, o fato de a família imigrante ter que ficar no Brasil mais tempo do que o esperado colocou os japoneses num dilema quanto à maneira de educar os filhos, pois estes começaram a crescer e assimilar a cultura brasileira. O modo nipônico de ensinar, influenciado por idéias nacionalistas ligadas à perspectiva de retorno ao território japonês, predominou até a Segunda Guerra Mundial, quando os japoneses viram-se obrigados a abandonar o sonho do regresso a seu país (Handa 1987; Vários Autores 1992).

$\mathrm{Na}$ cidade de São Paulo, principalmente no bairro da Liberdade e arredores, era freqüente as crianças japonesas irem à escola primária pela manhã e à tarde aprenderem o japonês com o professor Shinzo Miyasaki (professor da Escola Taisho). 
Entre 1925 e 1930, muitos filhos de agricultores vieram estudar nos ginásios da cidade. Esses jovens eram filhos de produtores de café do interior do estado e dos produtores de batata e tomate residentes na periferia da cidade - Itaquera, Taboão da Serra, Cotia, São Miguel etc. (Handa 1987). Alguns jovens que moravam na periferia vinham para a cidade e voltavam diariamente de trem, porém, os do interior moravam em pensões localizadas, sobretudo, no bairro da Liberdade, mas também em Pinheiros.

Samuel Lowrie, ao realizar uma pesquisa sobre a população negra, fez uma relação dos grupos escolares em que estudavam crianças de origem japonesa no ano de 1938. Segundo essa relação, havia crianças japonesas em todas as escolas da cidade, mas, de qualquer modo, em número inferior ao que encontramos em escolas japonesas, em 1932.

Baseando-nos em relatos dos entrevistados e em outras fontes documentais para o município de São Paulo, podemos dizer que havia diferentes tipos de escolas japonesas, por nós classificadas da seguinte maneira: a) escolas agrícolas construídas pelas companhias de imigração; b) escolas noturnas para jovens e adultos; c) escolas de língua japonesa para crianças, depois transformadas em escolas primárias isoladas e grupos escolares públicos; d) escolas primárias completas mantidas por particulares; e) escolas primárias completas mantidas por ordens religiosas e f) escolas primárias/médias profissionalizantes.

Dentre as escolas agrícolas construídas pelas companhias de imigração destacava-se a M'Boi, iniciativa da companhia Kaigai Kogyo Kabushiki Kaisha.

O Instituto de Prática Agrícola de São Paulo, mais conhecido como Escola Prática de Agricultura M'Boi, destinava-se a formar jovens capazes de ocupar posição de liderança na comunidade japonesa no Brasil. Dedicava-se ao ensino de técnicas agrícolas com aulas teóricas e práticas, além de língua portuguesa, japonesa, história e geografia do Brasil, conhecimentos gerais etc. De acordo com alguns autores, existiam escolas de práticas agrícolas em Registro e no Caxingui (periferia de São Paulo), mas não há maiores informações sobre elas (Vários Autores 1992). O Instituto de Prática Agrícola de São Paulo foi descrito por Bruno Lobo em 1932, acreditando-se que tenha servido como modelo para os demais. ${ }^{2}$

Já as escolas noturnas para jovens e adultos podiam ser encontradas na cidade de São Paulo e em outros locais. Um senhor que imigrou em 1914 , aos dois anos, conta que freqüentou quando jovem uma escola noturna no bairro de Campo Limpo para aprender o português: "À noite ele (o professor Kamaichiga) dava aula para os moços, dava aula para nós (...), 
tinha mais ou menos 20 alunos, tudo japonês. (...) (Cada um) pagava uma coisinha. Não tinha... Eles não falavam quanto, cada um dava quanto podia" (Entrevistado S).

Também na colônia de Itaquera, muito distante do centro, havia uma escola noturna: "Tinha aos domingos para as crianças e à noite para os moços que queriam estudar, não é? As aulas eram dadas durante a semana à noite" (Entrevistado TK).

Na periferia rural da metrópole havia, ainda, as escolas isoladas, que ofereciam até $02^{\circ}$ e $03^{\circ}$ ano primário, com classes mistas muitas delas; inicialmente escolas de língua japonesa para crianças, mais tarde transformadas em grupos escolares públicos. Com a entrevista de uma jun-nissei que chegou ao Brasil em 1923, com três anos, após o grande terremoto de Tóquio nesse mesmo ano, soubemos da existência de uma escola japonesa no Morumbi, na qual estudaram seus irmãos. Esta era destinada basicamente aos filhos de agricultores. Por meio de um casal que chegou ao Brasil em julho de 1934, ele com 23 anos e ela com 16, pudemos saber da existência de uma escola japonesa em Santo André, onde inclusive estudara sua filha mais velha. Confirmando a já mencionada preocupação dos pais japoneses com a educação dos filhos, um entrevistado que residia próximo a Taboão da Serra contou como seu pai fundara uma escola ali, logo após sua chegada:

Ele (o pai) que trouxe a escola que nós temos no bairro, ele que fez muito esforço (para criar) a Escola Pública (no bairro de Taboão da Serra). Era pública, mas era japonesa, também. Quer dizer que era escola pública e ficava junto com a japonesa. Então, quer dizer que eles construíram uma parte e deram pra escola pública e a outra era escola japonesa.(...) ( $A$ escola chamava-se) Escola Mista Nipo-brasileira.(...) Meu pai veio aqui em $30 \ldots$ Em 33 já construiu escola. (Entrevistado S)

As aulas eram ministradas nos dois idiomas e a escola era também freqüentada por crianças brasileiras. Essa escola era mantida pelas doações da comunidade, que pagava o salário do professor de japonês, pois a professora que ensinava português era paga pelo Estado. Além das doações da comunidade da região próxima a Taboão da Serra, houve, inicialmente, a ajuda do cônsul, porque o pai do entrevistado e o cônsul eram amigos. Durante a guerra essa escola não foi fechada, graças, em grande parte, ao apoio do inspetor de ensino da região, Francisco de Lima, com quem os japoneses estabeleceram vínculos ao longo do tempo. 
A grande preocupação dos japoneses com a educação de seus fiIhos também estava fortemente presente em Itaquera; e antes de as crianças freqüentarem um grupo escolar ou uma escola particular de nível primário, iam à escola dominical criada pelos moradores, como nos contou um antigo morador da Colônia.

Geralmente a família japonesa se preocupa muito pela educação, então começou com uma escola japonesa, escola nossa. Veio um professor de fora e criamos uma escola que chamava escola dominical, aos domingos. Então eles reuniam alunos e davam (...). Isso continuou alguns anos, de 1932 a 35. Esta escola dominical foi idealizada por um professor, ele morava em Pinheiros, chamava-se Kishimoto (...). Esse senhor, eu não sei (por)que eu era aluno, era menino, mas ele veio à colônia e fundou uma escola. (Funcionava em): uma casa de uma família particular. (...) Não sei quanto tempo ele (professor) ficou. (...) Depois nós transferimos ao professor Kuzita, esse senhor Kuzita morava aqui, né? (Entrevistado TK).

Com o passar do tempo a escola deixou de ser dominical e passou a

funcionar assim semanal, dia de semana, duas, três vezes por semana também. (...) era um curso de opção dos alunos, da família. Os pais pagavam uma mensalidade para os filhos estudarem porque tínhamos que manter professor, né?" (Entrevistado TK)

A primeira escola brasileira da colônia surgiu em 1938; essa escola particular de tipo isolada

foi mantida pela comunidade, então a comunidade fazia escola japonesa, mas se preocupou pela escola, educação nacional... E fundou-se aqui uma escola particular... tinha uma professora aí (...) E funcionava na sede, onde nós construímos para estudar. (...) Havia uma professora dando aula para todos, ela tinha que dividir. Era sacrifício... (Entrevistado TK)

Embora tal escola não pudesse oferecer os quatro anos do curso primário, havia o interesse por parte dos moradores para que se tornasse pública. Para tal era necessária uma autorização do inspetor estadual.

Nós não podíamos fazer 4 anos, (porque era) escola isolada. Aí entramos para a Secretaria da Educação, aí a Secretaria da Educação 
nomeou um inspetor, inspetor que vinha, era através desse inspetor do Estado que nós tínhamos autorização para manter funcionando. (...) A escola seguia o programa oficial. Só que nós não podíamos fornecer diploma, não é? E com isso o número de alunos aumentou, contratamos, um, dois, chegou até a três professores na escola. (...) E nisso (a colônia) foi entrando em contato com o governo para ver se o governo mantinha a escola. Porque nós éramos fiscalizados através de um inspetor, nós sempre tivemos um inspetor. O inspetor escolar é que autorizava o funcionamento da escola particular. (...) No fim do ano, para que os alunos pudessem passar de uma série, de um ano para o outro, a banca examinadora era fiscalizada pelo inspetor escolar, não inspetor de alunos, inspetor escolar que vinha da delegacia de ensino, mesmo, não é? (...) ( $A$ criançada) pegava as provas e fazia, mas não se entregavam os diplomas. (...) acontece que o governo (paulista) aceitou, mas não tinha professora que vinha porque era isolada, (...) tinha que andar pra condução. Então a colônia, a comunidade prontificou a dar um táxi. Então o governo fornecia a professora, nós fornecíamos alojamento... o galpão onde funcionavam as aulas e a condução da professora. (Entrevistado TK)

Pelo relato desse senhor podemos perceber que a fim de poderem continuar ensinando a língua japonesa às crianças, os dirigentes da colônia utilizaram-se de um artifício, qual seja, transformar a escola particular em escola pública, o que poderia significar para a população brasileira um processo de assimilação dos imigrantes japoneses. Assim, não haveria nenhum motivo para o governo fechar a escola, mesmo durante a Segunda Guerra, pois a escola já era quase pública, mantida com doações dos pais e com apoio do governo do Estado, e sem nenhum apoio do governo japonês. Como foi sintetizado pelo entrevistado:

(...) De fato, japonês se preocupa muito na educação dos filhos, né? Então como estamos no Brasil, educação tem que ser o primeiro... A língua nacional, a língua pátria e... Começamos com escola particular, da escola particular fomos entrando sempre em contato com o governo e até o governo chegar a receber e oficializar o Grupo Escolar. Então nós oficializamos o primeiro Grupo Escolar da colônia e me parece que nessa ocasião o professor era normalista, que eu falei. Em 1949 oficiou dessa escola particular para um Grupo Escolar da Colônia de Itaquera. E talvez em sessenta e poucos conseguimos um prédio próprio. O prédio então funcionava naquele lugar que a senhora foi visitar (o clube), o governo fez o galpão de madeira e o prédio funcionava ali. (Entrevistado T.K.) 
No final dos anos 50, a colônia doou $10 \mathrm{mil} \mathrm{m}^{2}$ de terra para o Estado, a fim de que se construísse o Grupo Escolar da Colônia de Itaquera, uma escola com cerca de oito classes. A partir do momento em que a escola passou a ser do governo, a comunidade não podia mais contratar os professores que quisesse, mas criou uma Associação de Pais e Mestres. A escola existe até hoje, mas atualmente são os novos moradores da região e não mais as crianças descendentes dos japoneses da colônia de Itaquera que a freqüentam.

As crianças moradoras da periferia rural de São Paulo não freqüentavam somente as escolas isoladas, pois os entrevistados da colônia nipônica de Itaquera falaram sobre a ida das crianças japonesas moradoras da região para as escolas da cidade. Segundo um deles:

Os estudantes da colônia, da nossa comunidade, já freqüentavam escolas da cidade. (...) Porque nós tínhamos só primário (na colônia) e, além do primário, só tinha que ser na capital ou na cidade vizinha. A cidade vizinha nossa era Moji das Cruzes. (Entrevistado TK).

Outro senhor nissei, nascido e criado na colônia de Itaquera, ao comentar sobre a educação das crianças japonesas nas décadas de 1920 e 1930, conta que "Naquele tempo já tinha muitos elementos que estudaram no Ginásio do Estado" (Entrevistado H).

Além do Ginásio do Estado (na época muito conceituado e disputado), algumas crianças de Itaquera - as que não conseguiam vagas lá - iam estudar no Ginásio Paulistano, que era particular, pois era a única opção para quem não conseguia entrar no Ginásio do Estado.

Havia também as escolas primárias completas mantidas por particulares, como a Escola Primária Taisho, talvez a mais antiga escola primária japonesa completa; ela foi criada por volta de 1914, contando com apenas três alunos que pagavam uma mensalidade de quatro mil-réis. Sua fundação oficial data de outubro de 1915, mas foi somente no ano seguinte que conseguiu um endereço fixo e mudou-se para o número 48 (não há certeza quanto ao número) da rua Conde de Sarzedas, no andar térreo de um sobrado que ficava no fim da ladeira; mais tarde essa escola mudou-se para a rua São Joaquim. ${ }^{3}$ Em janeiro de 1919 a Taisho foi reconhecida como escola particular, e no final do ano, em dezembro, a professora Antônia dos Santos, que era negra, começou a dar aulas de português (Handa 1987). De acordo com um exprofessor, Takeshita, a Escola Taisho foi criada pelo professor Miyazaki, que 
(...) era professor formado de escola de... língua estrangeira lá no Japão. Depois veio aqui... ele inventou essa escola, começou a ensinar. Isso foi porque tinha necessidade, naquele tempo tinha, ainda não existia nenhuma escola japonesa. Foi a primeira escola japonesa de São Paulo. Para filhos de japoneses. ${ }^{4}$ (Entrevistado Ta)

No início, a escola era administrada por dois japoneses - Yamada e Samejima - que haviam chegado ao Brasil muito antes do professor, e possuíam outras atividades além dessa. Um era médico - "o único médico japonês que havia" - formado no Japão e o outro era construtor. Pelo que foi relatado pelo professor entrevistado, um deles cuidava mais da parte financeira, o outro do funcionamento da escola. A escola contava com três salas - duas utilizadas para aulas e a outra servia de dormitório para os professores -, tinha turmas mistas e cerca de 80 alunos. Em 1929 a Taisho, com um subsídio do governo japonês, mudou-se para a rua São Joaquim.

(...) quando escola estava na Conde de Sarzedas, ... (era) um colégio feio, sabe! (o governo japonês) Deu ajuda. Aí mandou 168 contos... Aí, procurando, achamos esta casa de rua Conde de São Joaquim. Comprou de uma vez. Após a mudança a moradia ficou melhor. Agora nós (professores) ganhamos nosso quarto, até a nossa casa construir. Até onde melhorou muito. Melhorou muito, mas eu fiquei, dois, três anos, não é? (Entrevistado Ta)

Os alunos eram japoneses que não dominavam nem o português nem o japonês. Filhos de carpinteiros ou empregados domésticos, profissões comuns entre os japoneses em São Paulo, com idades variadas (de 5, 6 anos até 14,15 anos), que não trabalhavam a fim de ter tempo para estudar. O número de meninos e meninas matriculados era semelhante e utilizavamse livros japoneses para o ensino. Esses livros eram adquiridos no Brasil, pois: “(...) tem loja japonesa, aí na Conde de Sarzedas e Conselheiro Furtado. Onde vende esse material, materiais japoneses... livro para ler... Aluno que comprava. Igual os que usavam lá no Japão" (Entrevistado Ta).

Havia classes de manhã e à tarde. De manhã as aulas duravam quatro horas e à tarde de duas a três horas. As aulas de português eram dadas por professores brasileiros, e enquanto uma turma aprendia o idioma japonês, a outra aprendia o português. Os professores levavam as crianças para passear no Parque da Aclimação, local onde se realizava o undôkai - tradicional festejo anual para se comemorar o aniversário do imperador. 
A Escola Taisho não tinha, nessa época, qualquer contato com outras escolas da cidade, e, segundo um professor entrevistado, o governo não exercia controle sobre as atividades docentes. A escola parecia funcionar de acordo com seus interesses, ensinando o português, mas empenhando-se na transmissão dos conhecimentos pela língua japonesa. O controle mais efetivo sobre sua atividade vai se manifestar na década de 1930, durante o Estado Novo. Embora o governo japonês contribuísse esporadicamente, a manutenção da escola era realizada efetivamente pela população japonesa residente no bairro, com a contribuição mensal dos pais que ajudava a pagar o aluguel do primeiro prédio - e o ordenado dos professores. "Tinha a Associação Auxiliadora de Escola Japonesa (mantida e criada por comerciantes, mais ou menos em 1922-1923). Os membros pagavam mensalmente 5 cruzeiros, 10,20 cruzeiros, 50 cruzeiros. Aí, esse dinheiro que dava pra sustentar, pra pagar o professor" (Entrevistado Ta).

Não sabemos ao certo quantos alunos freqüentavam a Escola Taisho em seus dois prédios. O professor entrevistado afirma que "tinha oitenta e tantos", como já dito. As fotos que nos mostrou com alunos da primeira escola referem-se a uma turma masculina, composta por 28 meninos, e a outra feminina, com 21 meninas. Nas fotos referentes ao segundo prédio, duas são de turmas masculinas, e duas de turmas femininas. $O$ professor não nos informou se eram classes que funcionaram no mesmo ano (ele não conseguia distinguir os contornos dos rostos, por problemas de visão). Nas fotos com as meninas, uma delas é de uma turma de 15, outra de 22 alunas; nas com os meninos, uma é de 24 , outra de 18 alunos.

Outros entrevistados passaram pela escola quando crianças. Uma entrevistada que chegou ao Brasil em 1923 estudou na famosa Escola Taisho por menos de um ano, no final da década de 1920. Lembrava-se da professora dona Antônia, que ia embora a pé junto com ela para o bairro da Aclimação, e de que "a escola (...) era paga" (Entrevistada Mi).

Entre as entrevistadas temos uma senhora nissei (nascida em Promissão, em 1914, que não aprendeu o japonês porque seu pai achava que ela devia saber o português) que chegou a dar aulas nos anos de 1938-1939, nessa famosa escola, para alunos do $3^{\circ}$ ano que já sabiam falar o português. De acordo com essa senhora:

A Escola Taisho seguia a linha dos Grupos (estaduais), mesmo porque de lá os alunos iam entrar no ginásio, ginásio comum. Lá só tinha o primário. (...) Então a gente tinha que seguir o programa 
de ensino que dava normalmente no ensino. E geralmente a gente conseguia. (...) Dava História do Brasil, como se todo mundo fosse brasileiro mesmo, só que... alguns faziam aulas de japonês. (...) Nós éramos quatro professoras brasileiras e depois tinha os professores japoneses, que davam aulas de japonês, eles seguiam o programa do Japão. (Entrevistada C)

Outra escola do bairro Pinheiros pode ser comparada à Taisho. Uma entrevistada, nascida nesse bairro em 1928, disse que se lembrava de sua permanência na Escola Japonesa Yoseguaken durante três anos (1936-1939), tendo entrado na escola "quando tinha oito anos" (Entrevistada K). As aulas eram ministradas em japonês e havia muitos alunos. As turmas eram mistas e o número de meninos e meninas era praticamente igual. Quando indagada sobre a fundação da escola, essa senhora disse que já existia antes de 1936. As crianças iam à escola na parte da manhã e ficavam lá por quatro horas. Além de música e gramática japonesas, havia também as aulas sobre a história e a geografia do Japão dadas por três professores, que falavam, ensinavam e escreviam em japonês. Essa escola funcionava em regime de externato e internato, pois: "Além das crianças que moravam na capital, também tinha meninas do interior, que ficava internada na escola" (Entrevistada K).

Eram oferecidos às crianças seis anos de estudo e depois mais dois anos como colegial. O professor Aki era diretor da Escola Japonesa Yoseguaken e "formado, tem que ser formado". O governo japonês ajudava na manutenção da escola, tanto que: "(...) ele (professor $A k l)$ recebia também do - como chama? - mesada (o subsídio do governo japonês) lá do Japão também. (...) depois começou essa guerra (a Segunda Guerra Mundial), já não recebeu mais" (Entrevistada K).

Para realizar o tradicional undôkai, a escola alugava um campo próximo para as crianças; além disso havia teatrinhos para os pais, em japonês. A Escola Yoseguaken foi fechada no começo da Segunda Guerra Mundial.

É interessante observar que, embora as duas escolas fossem japonesas, parecia haver uma diferenciação entre elas, uma vez que a Taisho incorporou professores de língua portuguesa. Não temos condições de avaliar aqui em que medida esse fato teria influenciado no fechamento desta última durante o período da guerra, e até que ponto, por serem escolas que pareciam ter maiores vinculações com o governo japonês, teriam deixado de desenvolver (como constatamos no caso das escolas isoladas) estratégias que permitissem sua aceitação e sua incorporação no sistema oficial de ensino, embora os valores e a cultura japonesa aí continuassem presentes. 
Havia também em São Paulo as escolas primárias completas mantidas por religiosos. Na zona central da cidade funcionava o Colégio Católico Japonês São Francisco Xavier, citado por duas entrevistadas: uma nissei, nascida em 1928, que sabia da existência do colégio, e uma professora brasileira, nascida em 1919, que lecionou nessa escola de 1939 a 1943. Esse colégio, segundo uma professora entrevistada, funcionou na rua Tamandaré esquina com Barão de lguape até 1955. Depois mudou-se para o Ipiranga, onde funciona até hoje.

Essa última entrevistada nos diz que fez parte das primeiras turmas de professoras brasileiras; ela não sabe precisar quando foi fundada essa escola, mas diz que é anterior a 1939. A respeito da fundação do colégio, conta:

\begin{abstract}
Eu imagino, também não posso garantir, que o padre (Guido Deotoro) começou o trabalho na Igreja de São Gonçalo com a catequese dos japoneses, fazendo com catequese e tal, e daí surgiu a idéia pra ele de abrir um colégio, servindo para os filhos daqueles japoneses e para os japoneses adultos também, que decerto tinham aula lá de japonês à tarde; então acho que surgiu, tanto que a escola era na Liberdade, bem próximo da Igreja de São Gonçalo, rua Galvão Bueno esquina de Barão de Iguape; depois ele funcionou uns tempos na rua Tamandaré. (...) tinha funcionários em dois períodos; no período da manhã, a parte de alfabetização do primário de $1^{\text {a }}$ a $4^{\underline{a}}$ série e as professoras eram nomeadas pelo governo, na qualidade de professoras interinas. Estas professoras do período da manhã eram brasileiras (...). Agora, no período da tarde, a escola funcionava em japonês (...), daí eles tinham tudo em japonês, matemática, geografia, história, tudo em japonês, mas era particular. Aí o governo não tinha nada com isso e nem poderia saber que tinha, eles inspecionavam parte... (Entrevistada Z)
\end{abstract}

Os alunos eram todos japoneses, porém nem todos eram católicos, sendo que alguns alunos só freqüentavam a escola no período da tarde a fim de aprender o japonês. No período da manhã só havia professoras brasileiras. Nessa escola havia as quatro séries com classes separadas, nas quais estudavam, em média, 40 crianças, sendo um pouco superior o número de meninos. Realizavam passeios - de um deles, ao Guarujá, a entrevistada guardava ainda uma foto. O governo japonês não subvencionava essa escola, que durante a Segunda Guerra continuou funcionando.

Por fim, temos as escolas primárias médias profissionalizantes, muitas delas escolas de corte e costura para as moças, como a Escola de Corte 
e Costura Nipo-Brasileira e a Escola de Corte e Costura Akama, as primeiras escolas fundadas para moças em São Paulo. As jovens que se formavam nessas escolas eram "mais cotadas para o casamento" ao voltar às colônias do que aquelas que não as haviam freqüentado; muitas delas também montavam novas escolas de corte e costura no interior. Algumas dessas "escolas, quando bem aparelhadas, ensinavam também português e japonês, além de outras matérias de conhecimento geral. (...) Aliás, as escolas eram carinhosamente chamadas de "escolas de noivas'" (Vários Autores 1992, p. 132). Segundo dona Michie Akama, fundadora da Escola Akama, $80 \%$ das moças que vinham estudar em sua escola e voltavam para o interior casavamse muito bem e abriam uma escola lá mesmo; para tal, era preciso fazer um exame para tirar o certificado de professora de corte e costura.

Nascida no Japão, Michie Akama fundou a Escola de Corte e Costura Akama em 1932 (atualmente é o Centro Educacional Pioneiro, fazendo parte de uma fundação, juntamente com o Centro de Língua Japonesa). A idéia de criar uma escola, que categorizamos aqui como "profissionalizante", surgiu após dona Akama e o marido, um oceanógrafo, terem ficado um ano em Registro, interior de São Paulo, e visto moças sem objetivos na vida, nem possibilidade de estudar. Ao chegar à cidade de São Paulo, o casal criou uma escola de corte e costura para moças, do tipo pensionato. Em agosto de 1933, as aulas não mais se restringiam a corte e costura, pois havia também aulas de japonês, trabalhos manuais, culinária, etiqueta, tênis etc., enfim, tudo o que era necessário para uma futura dona de casa. A escola atendia à clientela da colônia japonesa do interior, sendo que $70 \%$ das alunas eram de origem japonesa. A partir de 1935, com a institucionalização dos exames de habilitação do magistério profissional de corte e costura, a escola criou um currículo para preparar as candidatas para tal exame. Aproxiximadamente 40 jovens conseguiam aprovação anualmente, e depois abriam suas escolas no interior do estado. ${ }^{5}$

Embora na colônia existissem muitas escolas que ministravam o ensino de língua japonesa, não havia ainda, na época, nenhuma que pudesse ser classificada rigorosamente como uma escola japonesa de nível médio. Assim, por sugestão do meu marido, Juiji, decidimos criar um curso de língua japonesa de nível médio, cuja inauguração deu-se a 7 de setembro de 1935, com a presença de várias personalidades ilustres. $^{6}$

No início, o curso constituía-se de classes de até $2^{a}$ série; posteriormente, estendemos até $3^{\text {a }}$ série. Mas as jovens, demonstrando um interesse cada vez maior pela língua japonesa, começaram 
a reclamar por classe de $4^{\underline{a}}$ série. Assim, admitimos professores de formação universitária no Japão, independentemente de questões econômicas. Incluímos também no programa de ensino atividades artístico-culturais como música, pintura, tanka (poesia japonesa) etc., visando proporcionar formação cultural das alunas também. Visando ainda enriquecer a vida doméstica, ministramos aulas práticas de culinária, ensinando-Ihes o preparo de conservas e tratamento de produtos alimentícios naturais, com o intuito de desenvolver habilidades manuais. Enfim, foram muitos os cursos e aulas práticas que ministramos. ${ }^{7}$

Esses cursos que utilizavam o mesmo material do Japão eram rápidos, durando de três a seis meses ou até um ano; o curso de língua japonesa era de quatro anos. Havia professores contratados do Japão, universitários, que davam três horas de aula. As aulas de português eram ministradas por uma professora brasileira. Quando a escola funcionava numa casa alugada na rua Conselheiro Furtado, possuía 20 alunas em média, que ficavam em regime de internato; ao mudar para a rua São Joaquim, o número de alunas aumentou para 150, das quais mais ou menos 30 eram internas e as demais voltavam todos os dias para casa. Durante a Segunda Guerra Mundial a escola ficou proibida de ensinar o japonês. Em virtude do movimento ShindoRemmei, que acreditava na vitória japonesa, dona Akama perdeu cerca de 50 alunas. Ao tirarem suas filhas da escola de dona Akama, os pais "colocavam(-nas) na escola que dizia que o Japão tinha ganho (...), na Escola Nippak na Castro Alves (também uma escola feminina)" (Entrevistada A).

Após o fim da Segunda Guerra, em vez de adotar prioritariamente matérias tipicamente japonesas, começou-se a seguir o mesmo currículo do curso médio brasileiro, com aulas de latim, francês, inglês e português, em razão do grande interesse da comunidade japonesa de se integrar à sociedade brasileira. ${ }^{8} \mathrm{O}$ governo japonês nunca deu nenhuma ajuda à escola, alegando - segundo dona Akama - falta de ética para com o governo brasileiro. A Escola Nippak, que teria absorvido alunas da escola de dona Akama, também foi citada por outro entrevistado, morador de Itaquera. A respeito dela, não conseguimos obter maiores informações, mas pelo que foi relatado pelos entrevistados ela se encaixaria no tipo de escola da região central, isto é, escolas particulares com primário completo. ${ }^{9}$

No tocante aos professores das escolas japonesas, é necessário registrar que, no início, havia nas colônias poucas pessoas qualificadas para desempenhar tal papel; as que possuíam maior nível de escolaridade acabavam por exer- 
cê-lo. Alguns haviam cursado até o colegial no Japão ou eram os melhores alunos do ginásio. O professor, de acordo com Tomoo Handa, era cotado como "um intelectual que não consegue puxar uma enxada". Vale ressaltar que o salário recebido pelo professor era baixo e, portanto, atraía poucas pessoas (Handa 1987, Vários Autores, 1992). Handa informa que, com o patrocínio do Consulado Geral do Japão, foi fundada em 1927 a Zaihaku Nihonjin Kyoikukai (Associação Educativa dos Japoneses Residentes no Brasil), que em 1929 se transformou em Zai São Paulo Nihonjin Gakkô Fukeikai (Associação de Pais da Escola dos Japoneses Residentes em São Paulo). A partir daí o Consulado começou a convidar os presidentes e diretores educacionais dos núcleos, ocorrendo a liberação de subvenções para a construção de escolas.

Em março de 1936, após reformular seus estatutos, a Zai São Paulo transformou-se em Burajiru Nihonjin Kyoiku Fukyu-Kai (Associação de Difusão do Ensino de Japoneses do Brasil). Apesar de as escolas se estruturarem cada vez mais, os professores ainda continuavam recebendo baixos salários. Em 15 de março de 1932, na rua São Joaquim, no Bunka Kyokai (atual Sociedade de Cultura Japonesa), ocorreu o $1^{\circ}$ Encontro para a Pesquisa Educacional, organizado pela Liga de Amigos da Escola Japonesa em São Paulo e, nessa ocasião, 57 professores de japonês se reuniram e discutiram intensamente a concessão de subsídios para os professores, pelo Consulado Japonês. Os subsídios eram necessários porque muitas vezes os professores ganhavam menos que operários braçais sem instrução. Como o salário deles vinha das mensalidades pagas pelos pais, o valor variava de acordo com o número de filhos matriculados na escola; muitas vezes os pais mandavam arroz e outros cereais ao professor. Um entrevistado morador do bairro do Campo Limpo, contou que "pagava uma coisinha. Não tinha... Eles não falavam quanto" (Entrevistado $S$ ).

Embora não tenha sido relatada por nenhum de nossos entrevistados a existência de seminários para o aprendizado do português, acreditamos ser importante registrar a preocupação dos professores japoneses em aprender a língua portuguesa a fim de continuarem exercendo seu ofício. Segundo Handa, entre o final de 1933 e janeiro de 1934, foram realizados nas cidades de São Paulo, Presidente Prudente, Lins e no núcleo de Registro, sob patrocínio da Liga dos Amigos da Escola Japonesa, seminários para o ensino da língua portuguesa aos professores japoneses. Esses seminários tiveram a orientação de professores brasileiros e contavam com o apoio da Secretaria da Educação; os professores aprendiam noções de gramática, geografia do Brasil, o significado das datas internacionais e dos principais personagens da história mundial. 
Saber falar o português tornara-se indispensável aos professores japoneses, pois para poder continuar lecionando tinham que passar por um exame que os habilitasse. Cinqüenta dias não eram suficientes para que se aprendesse uma língua, porém muitos japoneses não se intimidaram e se saíram bem nesses seminários, tanto que houve um número baixo de reprovações, causando grande espanto aos professores brasileiros.

Com a entrada de imigrantes mais habilitados para desempenhar 0 papel de professores, principalmente a partir de 1924, elevou-se o nível das aulas ministradas e as escolas passaram a ser mais estruturadas, contando com melhores instalações e material didático mais adequado.

É o caso da Escola Taisho, sobre a qual falou um entrevistado que veio para São Paulo em 1924. Ele havia pensado inicialmente em ir para os Estados Unidos, onde pretendia entrar em uma universidade agrícola, porém acabou vindo para o Brasil, a alternativa que lhe surgiu na época. Esse senhor contava com uma escolaridade razoável - freqüentara, no Japão, o curso universitário de economia política. Como veio sozinho, podia ir para qualquer lugar, mas achou melhor ir trabalhar em uma fazenda de café, a fazenda Guatapará, juntamente com uma família de japoneses com quem fez amizade durante a viagem de navio. Lá ficou trabalhando nas plantações de café durante cinco meses, período em que freqüentou o curso noturno para adultos existente na fazenda, para aprender a falar o português. Nessa mesma época, dava aulas de inglês para as filhas do administrador da fazenda. Ao chegar, sozinho, na cidade de São Paulo nesse mesmo ano, começou a lecionar na Taisho:

Justamente nesta ocasião a escola estava precisando um professor japonês; bom, então, pra mim era ótimo, então me ofereci, fui logo aceito. Porque eu cursei também universidade, lá no Japão, sabe? De modo que ensinar escola primária é muito simples, eu fiquei ensinando sete anos e meio. (Entrevistado Ta)

Outro entrevistado que também imigrou sem família, em 1938, foi ser professor na colônia de Bastos, no ano seguinte. Antes de ir para o interior, esse senhor havia trabalhado durante quase um ano no Banco Japonês Tosa, onde atendia os clientes. Ele havia cursado até o colegial em Tóquio e decidiu sair do Japão como um aventureiro. Sua intenção não era enriquecer e voltar para o seu país: "Meu destino de... meu destino no Brasil não é de dinheiro, né? É bom como sonho de jovens. Por isso que... trabalhei no banco, trabalhei na colônia japonesa, como professor japonês, diversas profissão também" (Entrevistado Y). 
Os alunos eram crianças japonesas, que faziam uma dupla jornada na escola. Esse imigrante ficou cinco anos "só dando aulas" e mesmo durante a guerra ficou "ensinando escondido" (Entrevistado Y).

Dona Akama, que imigrou com o marido no início da década de 1930, também está entre os imigrantes mais habilitados para o cargo de professor. Dona Akama diferencia-se dos demais entrevistados citados porque já havia feito o Curso Normal no Japão; portanto, exercer a função de professora no novo país não foi apenas uma decisão emergencial.

A partir dos anos 30 alguns professores que lecionavam em escolas japonesas já haviam feito o Curso Normal aqui no Brasil. Como nos relatou uma nissei, nascida em Promissão (região de Bauru), que freqüentou uma Escola Normal no interior, na qual era a única japonesa:

Naquela época, anos 30, não era como agora que tem escolas por toda parte. Tanto que Escola Normal eram pouquíssimas em São Paulo. (...) Aí fizeram uma escola em Bauru, Escola Normal, e aí era só fazer o exame e entrar. Eu fiz o primário, depois eu já entrei na Escola Normal. Depois de mim veio uma turma que tinha só uma moça (japonesa). (Entrevistada C)

Depois que se formou com menos de 16 anos (de forma que foi preciso falsificar o documento de identidade, para ter a idade mínima para poder lecionar), foi dar aulas na colônia de Bastos, na Escola Taisho de São Paulo e em outras escolas não-japonesas.

$\mathrm{Na}$ colônia de Itaquera também lecionaram professoras que haviam freqüentado alguma Escola Normal. A colônia tinha uma associação, chamada Associação dos Nikkeis, que ficava responsável pela contratação dos professores. Como nos foi relatado por um dos entrevistados:

Aqui nessa comunidade veio um casal, e o marido ensinava japonês, dava aula de japonês, era professor. Depois nós soubemos que a esposa era professora formada, professora normalista formada. (Portanto) ela poderia lecionar. Então começou, iniciou-se a escola de ensino em português. (...) Ela tinha formado aqui, normalista. (...) E tinha estudado em Promissão. (Entrevistado TK)

Depois desta professora, que "foi a pioneira, foi a primeira" professora normalista a dar aulas na colônia -, vieram mais duas nisseis normalistas, que davam aulas de português. 
Em síntese, analisando os relatos sobre as escolas e o ensino podemos afirmar que o surgimento dessas escolas ocorre principalmente para a preservação da cultura e dos valores japoneses (escolas particulares), mas, também, que sua criação servia para suprir as deficiências do sistema educacional brasileiro. No caso das escolas religiosas, sua criação demonstrava tentativas de integrar os japoneses à cultura nacional. Não há um padrão único na criação das escolas, mas existem pelo menos quatro tipos, como vimos:

1) as escolas surgidas da união de famílias, que parecem ter sido o tipo mais comum; surgem em virtude dos esforços e interesses dos pais em proporcionarem certo grau de escolaridade aos descendentes. Como exemplos temos a escola da colônia de Itaquera e a Escola Nipo-Brasileira;

2) as escolas fundadas por indivíduos com recursos para atender à demanda por educação da comunidade japonesa, como a Escola de Corte e Costura Akama;

3) as escolas criadas pelas companhias de imigração;

4) as escolas criadas por entidades religiosas.

De acordo com os entrevistados, o apoio do governo japonês foi pequeno. Há dois casos em que ocorreu: na Escola Taisho e na Escola Nipo-Brasileira de Taboão da Serra (só em sua fase inicial). Por outro lado, algumas escolas passaram a contar com o apoio do governo brasileiro, na medida em que se tornaram escolas públicas nipo-brasileiras, como a Escola Nipo-Brasileira e a da colônia de Itaquera.

A maioria das escolas citadas não foi fechada durante a Segunda Guerra Mundial, por contar com a ajuda de alguma pessoa influente ou pelo fato de ensinar a língua portuguesa.

Se na década de 1920 havia certa liberdade na criação e no funcionamento das escolas japonesas, pudemos constatar que algumas medidas nacionalistas durante o governo Vargas tiveram grandes efeitos sobre a educação nipônica; muitas escolas foram fechadas e a educação tipicamente japonesa ficou prejudicada, levando muitos pais japoneses a repensar a forma de educar seus filhos.

No Annuario do Ensino do Estado de São Paulo 1936-1937 há um discurso proferido pelo professor A. Almeida Júnior, diretor do ensino, na reunião dos professores particulares japoneses, em 20 de janeiro de 1937, 
que ilustra bem a preocupação do governo brasileiro com a assimilação dos imigrantes à sociedade nacional. O discurso intitula-se: "A Escola Primária Particular e a Nacionalização" e merece ter alguns trechos reproduzidos:

(...) O Brasil quer que os japoneses, uma vez radicados aqui, se tornem bons brasileiros. Para o Brasil, o filho do japonês, aqui nascido, é e precisa ser cidadão exclusivamente brasileiro; e, para alcançar esse objetivo, deve trabalhar a escola tanto oficial como particular. A tarefa primordial da escola é a unificação nacional, a formação e o cultivo do sentimento da pátria. Para consegui-lo, é mister que os seus professores sejam brasileiros. Não se compreende que um professor primário japonês, ensinando a crianças no Brasil, seja um bom instrumento nacionalizador. Por mais esforço que faça, por mais sincero que seja, não o conseguirá: falta-Ihe o domínio da língua pátria, falta-Ihe o espírito nacional, falta-Ihe a tradição. Por isso, o ideal, que havemos um dia de atingir, é que em toda a superfície do Brasil só encontremos, nas escolas primárias, mestres de nacionalidade visceralmente brasileira. (...) (...) onde quer que se instalem escolas particulares, devem estas subordinar-se à orientação nacional e cooperar com as escolas públicas na formação do sentimento de pátria brasileira. (pp. 418-419) (grifos nossos)

O xenofobismo desse período pode ser constatado em outro texto do Annuario do Ensino do Estado de São Paulo 1935-1936, ao apontar o caráter desnacionalizador das escolas particulares, principalmente as estrangeiras, e também a necessidade de que o país não permita a entrada de um número muito grande de imigrantes.

Entre os problemas da escola particular, avulta por fim a questão da sua possível acção desnacionalizadora. Não nos assusta, como a muitos, a duvidosa dysgenia representada por esta ou aquella corrente immigratoria. Preocupa-nos, porem, o perigo certo da falta de assimilação social do immigrante e do filho do immigrante. Discutindo o problema, para os Estados Unidos, Raymond Pearl demonstrou, com princípios hauridos na Biologia, que não ha necessidade de vedar as fronteiras a nenhuma raça. O que é indispensável é o trabalho incessante de homogeneização nacional do elemento importado, trabalho que deve caber a órgãos assimila-dores especiais. Por isso, impõe-se fechar, de tempos em tempos, a porta ao immigrante, a fim de que a nação 
tenha tempo de digerir... É a applicação social de um princípio de hygiene alimentar. Pois esse órgão assimilador é a escola primária, quer pública, quer particular.

Para isso, deve ella ser a escola "commum", que mistura classes sociaes e nacionalidades, e onde o menino extrangeiro se dilue e se sente absorvido. É a escola nacional de dia longo, na qual o filho do immigrante passa occupado quasi todo o seu tempo, longe do ambiente desnacionalizador da própria casa. É a escola que obriga o alumno, na sala de aula e no recreio, no estudo e nas festas, a tagarelar em nossa língua, a cantar os nossos cantos, a estudar o nosso passado, a rir com as nossas anedotas, a emocionar-se com o nosso folk-lore. Uma escola onde a criança não fala, não tem recreio, não é grande coisa, como força assimiladora. (p. 248)

Uma dessas medidas determinava que as escolas estrangeiras encaminhassem à Secretaria da Educação exemplares dos livros de língua estrangeira para serem examinados.

As medidas tomadas por Getúlio Vargas para conseguir uma rápida integração dos estrangeiros à sociedade brasileira foram, a partir de 1933, a proibição à entrada de "elementos das raças negra e amarela de qualquer procedência". Tornou-se obrigatória a realização de um exame de sanidade física e mental para qualquer estrangeiro que desejasse morar no país ou naturalizar-se (Carneiro 1988, p. 104).

Em 1934, foi promulgada a lei das cotas, que limitava em apenas $2 \%$ anuais a entrada de imigrantes estrangeiros no Brasil. O número-limite estabelecido para os japoneses foi de 2.711 imigrantes. ${ }^{10} \mathrm{O}$ grupo japonês foi muito prejudicado por tal medida, pois atravessava o seu auge migratório, atingindo mais de 20 mil imigrantes e tratava-se de uma imigração mais recente (25 anos), se comparada com outros grupos étnicos. Em 1937, a Constituição, de acordo com o artigo 145, determinava a nacionalização dos bancos, sendo estipulado um prazo de tolerância. Por fim, em 1938, ficou proibido nas zonas rurais o ensino de qualquer língua estrangeira para menores de 14 anos. Essa medida impediu que os imigrantes continuassem aprendendo a língua de seus antepassados, pois dificilmente alguém continuava freqüentando as escolas da zona rural após os 14 anos. Porém, a comunidade nipônica ignorava essa lei e continuava a ensinar a língua japonesa. É claro que, estando proibido por lei, o ensino da língua japonesa era feito às escondidas, com aulas ministradas por professores particulares em locais secretos - eram as chamadas aulas itinerantes. Essas classes, ao serem revistadas, poderiam rapidamente se transformar em locais de trabalho ou qualquer outra coisa 
que não levantasse suspeita a respeito do ensino (Handa 1987). Outras vezes eram realizadas "mediante acordo tácito com as autoridades locais" (Ando 1976, p. 186).

Inúmeras críticas surgiram a esse novo modo "clandestino" de educar as crianças. Perguntava-se a validade dos métodos utilizados para continuar ensinando os ideais japoneses; como crianças com medo de serem descobertas a qualquer momento poderiam aprender tranqüilamente o que era ensinado etc., o que fez com que essas aulas às escondidas não se generalizassem.

Em 25 de dezembro de 1938 todas as escolas de língua estrangeira foram fechadas, em sua maioria alemãs, japonesas (219 escolas) e italianas (Handa 1987, p. 626). Caso ainda continuassem funcionando seriam consideradas clandestinas. Apesar da proibição e do grande número de escolas fechadas, de acordo com a História da expansão dos japoneses no Brasil, o número de escolas primárias que ainda continuavam funcionando, em março de 1939, perfazia um total de 486.

Também em abril de 1933, o governo paulista adotou medidas nacionalistas mais severas que as federais, que afetaram as escolas e o ensino estrangeiros, como a proibição do ensino de língua estrangeira a crianças menores de 10 anos de idade; o exame de habilitação para o professor de língua estrangeira e a prévia aprovação dos livros de ensino dessa disciplina pelas autoridades de fiscalização, além da proibição de livros didáticos prejudiciais à formação do espírito nacional brasileiro (Vários Autores 1992, p. 128).

Outra medida que afetou imensamente as escolas estrangeiras foi a proibição de que estrangeiros exercessem o cargo de diretor ou proprietário de escola, qualquer que fosse a escola, particular ou não. Outro fato de impacto, em 1939, foi a criação do Departamento de Imprensa e Propaganda (DIP), responsável pela censura a jornais e revistas estrangeiros, que exigia a tradução para o português das principais matérias e impunha a criação de uma seção escrita em português. O jornal Nippak Shimbum era o único que já possuía uma página inteira redigida em português. Ainda em 1939 o governo promulgou um decreto sobre obrigações escolares em nível estadual que enfatizava a nacionalização das escolas particulares; os artigos $3^{\circ}, 4^{\circ} \mathrm{e}$ $5^{\circ}$ determinavam que 0 ensino da língua estrangeira não poderia ultrapassar duas horas diárias, que os programas de comemoração de escolas particulares e os livros didáticos deveriam obter aprovação da Secretaria da Educação com antecedência, não sendo permitidos atos ou louvações de espírito estrangeiro. (Handa 1987, p. 597). 
Para os imigrantes o ensino só poderia ser dado adequadamente na língua materna, porém os brasileiros consideravam essa atitude uma traição ao movimento de nacionalização existente. Para poderem se defender da política de assimilação imposta pelo governo Getúlio Vargas, os japoneses intensificaram o movimento em prol do espírito japonês (Yamato Damashi). No Japão, o nome desse movimento era Nihon Seishin Undoo (Movimento em Prol do Espírito Japonês) e seu objetivo era divulgar a superioridade do povo japonês.

A política nacionalista brasileira e a situação de guerra, embora tenham implicado dificuldades para as famílias e escolas japonesas, parecem não ter causado na metrópole de São Paulo alterações tão profundas no tocante ao campo educacional, ao menos não logo de imediato, pois muitas das escolas aqui existentes continuaram em funcionamento. Se no interior a freqüência às aulas era feita às escondidas e à noite, caracterizando uma estratégia de resistência dos japoneses necessária para poder continuar com um ensino "seu", em São Paulo, tanto na região central como na periferia, parece que as estratégias foram outras - os japoneses conseguiram estabelecer vínculos com as autoridades escolares nacionais que Ihes permitiram manter o funcionamento das escolas por eles criadas, mantidas e controladas.

Mas as repercussões da guerra no campo educacional vão se manifestar indiretamente e ao longo do tempo: com a derrota do Japão, os projetos que se concretizariam com o retorno àquele país são interrompidos; há uma mudança na representação da sociedade brasileira, no caso, paulista, que passa a ser vista como aquela em que os filhos devem se inserir em escalões mais altos. Mudam assim os investimentos das famílias japonesas, não só no plano econômico, mas especialmente no educacional: a educação escolar nacional, e não mais a "japonesa", passa a ser prioritária. A importância da escola japonesa no processo de ascensão social diminui.

A análise de como foram sendo criadas as escolas japonesas e das vivências no campo educacional das famílias japonesas em São Paulo levanos à reflexão sobre alguns pontos que julgamos importantes na discussão sobre a prática de uma educação igualitária num contexto de diferenças socioculturais.

Os órgãos educacionais locais sofreram pressões para equacionar, de um lado, a forte demanda por escolas, canalizada preferencialmente para escolas particulares japonesas, na ausência das oficiais, e, de outro, o constrangimento político para impedir a existência dessas escolas. As estratégias desenvolvidas por famílias e grupos japoneses em diversos bairros de São Paulo, construindo e colocando em funcionamento escolas para seus 
filhos e depois unindo-se ao governo estadual ou municipal para mantê-las como escolas nipo-brasileiras, permitem visualizar a riqueza que existe no estudo das demandas por educação de vários grupos. Também permitem pensar como as próprias famílias podem se antecipar ao Estado na solução de questões educacionais, enfrentando com maior clareza a questão da diferenciação sociocultural.

Como vimos, os japoneses (assim como vários outros grupos de imigrantes) conviveram em São Paulo, por opção própria ou por imposição, com dois tipos de educação: 1) a nacional, ministrada em escolas oficiais e também em escolas japonesas, que atendia tanto às necessidades de comunicação e conhecimento de uma sociedade na qual se inseriam como grupo diferenciado, como também às necessidades de um aprendizado para participar do mercado de trabalho e de produção e circulação de mercadorias da metrópole; 2) a japonesa, ministrada em escolas particulares de diferentes tipos e nas nipo-brasileiras, procurando atender à necessidade fundamental de manter os vínculos com a cultura oriental de origem, negada geralmente pelas escolas oficiais.

A escola oficial, mesmo quando se estruturando em uma sociedade multicultural como a paulistana, dificilmente conseguiu dar conta da diferenciação sociocultural, a não ser pela negação das bagagens culturais dos diferentes grupos. O mesmo vale para as populações negras e rurais no início do século, e mais recentemente em relação aos migrantes pobres oriundos do nordeste do país.

O enfrentamento da questão da diferenciação se dá geralmente pela negação da cultura daquele considerado mais fraco no momento, e não pela apropriação e pela discussão da própria diversidade. Esse fato, parece-nos, tem ocorrido historicamente com os imigrantes (e migrantes) recém-chegados a São Paulo, colocando-lhes dilemas e conflitos por terem que optar entre as duas culturas. Essa mesma orientação, parece-nos, é a que está por trás, atualmente, da negação da educação "brasileira" em nome de uma educação "estrangeira" que melhor atenderia às necessidades da globalização. A cultura nacional é agora considerada como de segunda categoria. Seria este o caminho a seguir, ou seria necessário discutir a questão da diversidade?

\section{Notas}

1. "Família em São Paulo: As especificidades estruturais e conjunturais da mediação indivíduo e sociedade". Projeto Integrado. Subprojeto 3: "Vida familiar de diferen- 
tes grupos étnicos em São Paulo e Campinas: Educação, lazer e consumo cultural em cidades em rápida transformação". São Paulo, Ceru/CNPq, 1994.

2. Lobo, B., De japonez a brasileiro (adaptação e nacionalisação do immigrante). Rio de Janeiro: Typ. Do Dep. Nacional de Estatística, 1932, pp. 153-156 e 159. Este é um livro bastante interessante que se preocupa em apresentar o povo japonês aos brasileiros; para tal, descreve o território japonês, a história do Japão, a organização social dos japoneses, suas características "morpho-biologicas" etc. Enfim, tenta mostrar a importância de o Brasil continuar recebendo os imigrantes japoneses. Vale lembrar que já estávamos vivendo em um ambiente de nacionalização no Brasil.

3. Sobre a região central na qual moravam os japoneses, ver Araújo 1940. Tomoo Handa nos diz que a escola ficava no número 48 da rua Conde de Sarzedas, mas segundo o livro Uma epopéia moderna: 80 anos da imigração japonesa no Brasil (1992, p. 143), a escola Taisho ficava no número 38 da Conde de Sarzedas.

4. "O professor Miyazaki permaneceu solteiro até sua morte, em junho de 1924. Era baixo, atarracado, com uma constituição física sugerindo muita saúde e, bem ao estilo de um orgulhoso samurai, vestia roupas escuras, velhas de tanto usar, e um chapéu engordurado, colocado impecavelmente sobre a cabeça. Para mim, ele tinha a aparência de um professor de literatura clássica chinesa, da Era Meiji (1868-1911). Ele realmente gostava de crianças e nos nove anos de profissão ensinou com o mesmo ânimo com que havia começado a fazê-lo" (Handa 1987, p. 177).

5. Álbum Comemorativo do $50^{\circ}$ Aniversário do Instituto Educacional "Dona Michie Akama" (Colégio Pioneiro). São Paulo, 1985 (escrito em português e japonês).

6. Idem, p. 6.

7. Idem, ibidem.

8. Idem.

9. Na época, a Segunda Guerra causou uma divisão na colônia japonesa, pois havia os que acreditavam na vitória japonesa, conhecidos como vitoristas ou nãoconformados (kachigumi), e os chamados derrotistas ou conformados (makegumi), que haviam aceitado a derrota japonesa. "O ódio e a intriga dividiram a comunidade nikkei (isto é, descendentes de japonês), propiciando o surgimento da Seita Terrorista Shindo-remmei, composta por fanáticos nacionalistas que pregavam a teoria da invencibilidade japonesa. Esses radicais espalhavam panfletos divulgando a vitória nipônica, valendo-se, inclusive, de fotos grosseiramente forjadas, e praticavam atos de terrorismo contra propriedades, lavoura etc. Pressionavam com ameaças - até mortes ocorreram - seus patrícios que não compactuassem de suas convicções ou lhes fizessem oposição. Como se viu, essas posições políticas interferiram no funcionamento das escolas japonesas. Nesse clima de medo e confusão é que ressurgiram os jornais nikkeis, cada qual procurando posicionar-se no confronto 'makegumi' x 'kachigumi' que assumira perigosas proporções" (Vários Autores 1992, p. 318).

10. Ando 1976. De acordo com Tomoo Handa, essa lei foi decretada em 18/7/1933 (1987, p. 186).

Recebido para publicação em junho de 2000. 


\title{
Japanese families oral history:topics for the history of brazilian education
}

\begin{abstract}
This paper continues a long lasting research that analyses the educational field in São Paulo and the different forms assumed by the need of instruction of different sectors of the rural and urban population. We focus on the segment represented by the Japanese immigrants' families which came to São Paulo from 1908.

We present the results obtained by means of oral reports, a privileged source for collecting data. It allowed, on the one hand, to seize the educational representations and practices of these Japanese groups and, on the other hand, to obtain valuable information about the still unknown Japanese school-net created by this group within São Paulo society.
\end{abstract}

\section{Bibliografia}

ANDO, Z. Estudos sócio-históricos da imigração japonesa. São Paulo: Centro de Estudos Nipo-Brasileiros, 1976.

ARAÚJO, O. E. "Enquistamentos étnicos". Revista do Arquivo Municipal de São Paulo (45). 1940, pp. 227-246.

CARNEIRO, M. L. O anti-semitismo na era Vargas: Fantasmas de uma geração (1930-1945). São Paulo: Brasiliense, 1988.

DEMARTINI, Zeila de B. F. "Memórias de velhos mestres da cidade de São Paulo e seus arredores". Relatório de pesquisa. São Paulo: Ceru, 1988.

"Viagens vividas, viagens sonhadas: Os japoneses em São Paulo na $1^{\underline{a}}$ metade deste século". Reunião Anual da Anpocs, 19. Caxambu, 1995.

HANDA, Tomoo. O imigrante japonês: Histórias de sua vida no Brasil. São Paulo: T.A. Queiroz/Centro de Estudos Nipo-Brasileiros, 1987.

MIYAO, S. "Posicionamento social da população de origem japonesa". In: SAITO (org.). A presença japonesa no Brasil. São Paulo: T.A. Queiroz/ Edusp, 1980.

VÁRIOS AUTORES. Uma epopéia moderna: 80 anos da imigração japonesa no Brasil. São Paulo: Hucitec/Sociedade Brasileira de Cultura Japonesa, 1992. 